\title{
Pencarian Rute Terpendek Menggunakan Algoritma Bellman-Ford (Studi Kasus: PT. JNE Medan)
}

\author{
Ester Tetri H. Hutasoit \\ Program Studi Teknik Informatika, STMIK Budi Darma, Medan, Indonesia \\ Email: hasianahutasoit@gmail.com
}

\begin{abstract}
Abstrak-Setiap manusia ingin sampai ke tujuan dengan tepat waktu. Tetapi sering kali kemacetan menyebabkan keinginan manusia terhambat. Oleh karena itu, dibutuhkan suatu cara untuk menanggulangi masalah tersebut yaitu dengan mengetahui jarak tempuh minimum untuk mencapai suatu tempat. Bidang jasa merupakan bidang yang menawarkan pelayanan dengan membantu konsumen dalam berbagai hal. Bidang jasa merupakan bidang yang tak akan pernah mengalami kebangkrutan meski dalam kondisi sulit sebab setiap orang sudah pasti membutuhkan bantuan orang lain dalam menuntaskan atau meyelesaikan berbagai hal. Jasa pengiriman barang merupakan salah satu bidang jasa yang paling banyak di gunakan khususnya dalam menghemat waktu maupun biaya (cost). Dalam jasa pengiriman barang, rute pengiriman barang menjadi sangat penting karena tanpa adanya rute yang terstruktur, pengiriman barang menjadi tidak tepat waktu dan bisa merugikan kepada perusahaan itu sendiri. Kerugian yang akan dialami oleh perusahaan adalah waktu pengantaran barang menjadi lebih lama karena jarak pengantaran pun menjadi lebih jauh. Dalam penelitian ini dilakukan penerapan perhitungan menggunakan algoritma BellmanFord yang bertujuan untuk mencari jalur terpendek dari kantor PT. JNE Medan menuju Helvetia. Algoritma yang digunakan adalah Bellman-Ford. Algoritma Belmman-Ford digunakan untuk menghitung semua jalur dari tempat asal ke tempat tujuan yang terbentuk dalam suatu graf agar di temukan jalur terpendek.
\end{abstract}

Kata Kunci: Bellman-Ford, Rute Terpendek

Abstract-Every human being wants to get to his destination on time. But often congestion causes human desires are blocked. Therefore, we need a way to overcome this problem by knowing the minimum distance to reach a place. The service sector is a field that offers services by helping consumers in various ways. The service sector is a field that will never experience bankruptcy even in difficult conditions because everyone certainly needs the help of others in completing or completing various things. Freight forwarding services are one of the services most widely used, especially in saving time and costs (cost). In the freight forwarding service, the route of shipping the goods becomes very important because without a structured route, the delivery of goods becomes not timely and can be detrimental to the company itself. The loss that will be experienced by the company is that the delivery time will be longer because the delivery distance will be further. In this study the calculation of the application using the Bellman-Ford algorithm is performed which aims to find the shortest path from the office of PT. JNE Medan to Helvetia. The algorithm used is Bellman-Ford. The Belmman-Ford algorithm is used to calculate all paths from origin to destination formed in a graph to find the shortest path.

Keywords: Bellman-Ford, Shortest Route

\section{PENDAHULUAN}

Pada era globalisasi, produk atau jasa pengiriman paket yang bersaing dalam satu pasar semakin banyak dan beragam akibat keterbukaan pasar. Hal ini juga mengharuskan setiap perusahaan menyusun kembali strategi. Sehingga terjadilah persaingan antar produsen untuk dapat memenuhi kebutuhan konsumen serta memberikan kepuasan kepada pelanggan secara maksimal, karena pada dasarnya tujuan dari suatu bisnis adalah untuk menciptakan rasa puas pada pelanggan. Salah satu tindakan untuk memuaskan konsumen adalah dengan cara memberikan pelayanan kepada konsumen dengan sebaik-baiknya.

Bidang jasa merupakan bidang yang menawarkan pelayanan dengan membantu konsumen dalam berbagai hal. Bidang jasa merupakan bidang yang tak akan pernah mengalami kebangkrutan meski dalam kondisi sulit sebab setiap orang sudah pasti membutuhkan bantuan orang lain dalam menuntaskan atau meyelesaikan berbagai hal. Jasa pengiriman barang merupakan salah satu bidang jasa yang paling banyak digunakan khususnya dalam menghemat waktu maupun biaya (cost). Jasa pengiriman sangat membantu mengirimkan barang kepada seseorang. Entah jaraknya memang sangat jauh, tidak begitu jauh, yang pasti perusahaan pengiriman memiliki jasa dalam sampainya benda yang dikirim kepada yang dituju.

JNE (Jalur Nugraha Ekakurir) merupakan perusahaan kurir dan logistik terbesar yang yang didukung secara Online yang tersebar luas di Indonesia, melayani pengiriman Express di Indonesia merupakan layanan regular mencapai kota dan kabupaten tujuan di seluruh Indonesia. Produk layanan ini sangat bervariasi yang disertai laporan penyampaian secara otomatis melalui layanan SMS adalah merupakan produk andalan JNE saat ini. Walaupun layanan JNE berpengaruh terhadap faktor lain seperti cuaca dan layanan penerbangan, namun dengan adanya jaminan uang kembali merupakan komitmen JNE untuk memberikan pelayanan terbaik kepada pelanggan.

Dalam kehidupan sehari-hari selalu dilakukan perjalanan dari suatu titik atau lokasi ke lokasi lainya dengan mempertimbangkan efisiensi jarak atau biaya (cost), sehingga dalam pengantaran barang sering terjadi keterlambatan disaat pengantaran barang terhadap konsumen. Maka diperlukan penentuan jarak atau lintasan terpendek yang merupakan suatu permasalahan untuk menemukan sebuah jalur antara dua node dengan jumlah bobot minimal, maka diperlukan ketetapan dalam menentukan lintasan tercepat antara titik atau lokasi yang akan ditempuh. Proses pengantaran barang dari Kantor PT. JNE Medan ke penerima menggunakan mobil agar dapat 
mempermudah sampainya barang ke penerima tanpa harus takut dengan kendala cuaca. Hasil penentuan jalur terpendek nantinya akan menjadi pertimbangan dalam pengambilan keputusan untuk menunjukkan jalur yang akan ditempuh sehingga meminimalisasikan waktu dalam perjalanan. Karena dalam pengantaran barang kepada konsumen sering terjadi keterlambatan dan tidak sampai di tujuan. Hal tersebut terjadi karena sangat mempengaruhi tingkat kepuasan pelanggan. Misalnya seorang kurir tidak memahami lokasi dalam pengantaran barang, sehingga barang yang di kirim kepada konsumen tidak tepat waktu sampai maka digunakan rute atau lintasan terpendek.

Pada penelitian sebelumnya yang dilakukan oleh Paska Marto Hasugian dengan judul "Analisa Dan Implementasi Algoritma Bellman-Ford Dalam Menentukan Jalur Terpendek Pengantaran Barang Dalam Kota" berdasarkan pengujian dapat disimpulkan Algoritma Bellman-Ford adalah salah satu algoritma yang dapat digunakan untuk melakukan proses pencarian Bellman-Ford dapat mencari jalur serta menghitung jalur dengan cara paralel, dalam arti masing-masing simpul dapat melakukan setiap prosesnya secara bersamaan dalam satu waktu (multiproses)[1]. Pencarian rute terpendek dapat dimodelkan dalam bentuk graf. Dalam pencarian rute terpendek pada suatu masalah terdapat banyak algoritma yang dapat digunakan. Pemilihan algoritma yang optimum selalu menjadi permasalahan dalam pencarian rute terpendek, dimana masing-masing algoritma memiliki kekurangan dan kelebihan tersendiri. Algoritma yang dapat digunakan untuk menentukan rute terpendek untuk mencari lintasan atau jalur terpendek dalam graf dapat dilakukan dengan beberapa algoritma, salah satunya adalah Algoritma Bellman-Ford. Algoritma merupakan kumpulan perintah-perintah untuk menyelesaikan suatu masalah tertentu. Algoritma Bellman-Ford, digunakan untuk menetuan rute atau lintasan terpendek untuk pencarian jalur dalam suatu perjalanan.

\section{METODE PENELITIAN}

\subsection{Graf}

Sebuah graf $\mathrm{G}=(\mathrm{V}, \mathrm{E})$ terdiri dari himpunan $(V 1, V 2, V 3 \ldots)$ yang elemen elemennya disebut simpul. Dan himpunan $\mathrm{E}=(e 1, e 2, e 3, \ldots$.$) yang elemennya disebut bujur. Sedemikian sehingga setiap bujur e yang dinyatakan$ sebagai pasangan simpul (V1, V2) (Deo Narsingh, 1989). Simpul simpul V1 dan V2 yang diasosiasikan dengan simpul simpul akhir dari $e$.

Jenis-Jenis Graf

1. Graf tidak berarah dan berbobot (undirected graph)

2. Graf berarah dan berbobot (directed graph)

3. Graf tidak berarah dan tidak bebobot

4. Graf berarah dan tidak berbobot

\subsection{Algoritma Bellman-Ford}

Algoritma Bellman-Ford yang ditemukan oleh Richard E. Bellman, seorang ahli matematika yang terlahir di New York 1920. Algoritma Bellman-Ford menghitung jarak terpendek (dari satu sumber) pada sebuah graf berbobot. Maksudnya dari satu sumber ialah bahwa ia menghitung semua jarak terpendek yang berawal dari satu titik node. (Bayu Aditya Pradhana, 2006). Maksud dari sumber tunggal ialah bahwa algoritma menghitung semuah jarak terpendek yang berawal dari satu titik. Di samping itu algoritma ini menggunakan $d[u]$ sebagai batas atas dengan jarak $d[u, v]$ dari $u$ ke $v$. Algoritma ini melakukan inisialisasi jarak titik sumber ke titik nol dan semua titik lainnya (sampai tak hingga).

Secara progresif algoritma ini melakukan perbaikan (updating) jarak pada setiap titik sumber ke titik $v$ di dalam $V$ hingga dicapai lintasan dalil Boolean TRUE yaitu jika grafik mengandung lingkaran tidak negatif maka titik dapat dicapai dari titik sumber, dan dalam kondisi lain dikatakan Bollean FALSE. Algoritma Bellman-Ford sebagai berikut :

1. Initialize-Single-Source $(G, s)$

2. for each vertex $\mathrm{i}=1$ to $V[G]-1$ do

3. for each edge $(u, v)$ in $E[G]$ do

4. $\operatorname{RELAX}(u, v, w)$

5. For each edge $(u, v)$ in $E[G]$ do

6. if $d[u]+w(u, v)<d[v]$ then

7. return FALSE

8. return TRUE

\section{ANALISA DAN PEMBAHASAN}

Untuk menentukan pencarian rute minimum yang dimaksud dapat dicari dengan menggunakan graf. Graf yang digunakan adalah graf berbobot, yaitu graf yang setiap sisinya diberikan suatu nilai atau bobot. Dalam kasus ini yang bermaksud berupa jarak. Lintasan terpendek dengan titik awal $u$ dan titik tujuan $v$ didefinisikan sebagai 
lintasan dari $u$ ke $v$ dengan bobot minimum dan berupa lintasan sederhana (simple path). Dalam tahap analisa akan menguraikan bagaimana proses pencarian rute terpendek dengan menggunakan algoritma Bellman-Ford. Jalur perjalanan dari kantor JNE Bridgen Katamso menuju tempat tersebut pada proses pencarian.

PT. JNE Medan berada pada jalan Bridgen Katamso ingin menuju Helvetia , tetapi jarak yang dapat ditempuh belum diketahui sehingga dicari jalur terpendek menuju tempat tersebut. Dalam bidang jasa yang paling banyak digunakan khususnya dalam menghemat waktu maupun biaya (cost) dan algoritma yang digunakan adalah algoritma Bellman-Ford. Dalam jasa pengiriman barang, rute pengiriman barang menjadi sangat penting. Kerugian yang akan dialami oleh perusahaan adalah waktu pengantaran barang menjadi lebih lama karena jarak pengantaran pun menjadi lebih jauh karena tidak adanya jalur terpendek dalam pengantaran barang menuju konsumen.

Algoritma Bellman-Ford membutuhkan parameter tempat asal, dan tempat tujuan. Hasil akhir dari algoritma Bellman-Ford ini adalah jarak terpendek dari tempat asal ke tempat tujuan beserta jalurnya. Algoritma Bellman-Ford menghitung jarak terpendek dari satu sumber pada graf berbobot, maksudnya adalah algoritma Bellman-Ford menghitung semua jarak atau lintasan terpendek dari titik awal ke titik tujuan.

PT. JNE Medan berada pada Jalan Brigjen Katamso ingin menuju ke Helvetia (Jalan Kapten Muslim). Terdapat beberapa jalur yang dapat ditempuh, tetapi jarak terdekat yang dapat ditempuh belum diketahui sehingga dicari jalur terpendek menuju Helvetia (Jalan Kapten Muslim) menggunakan algoritma Bellman-Ford.

Pada proses pencarian ada 13 jalan yang akan diteliti yang dituangkan dalam bentuk graf. Adapun gambarnya sebagai berikut :

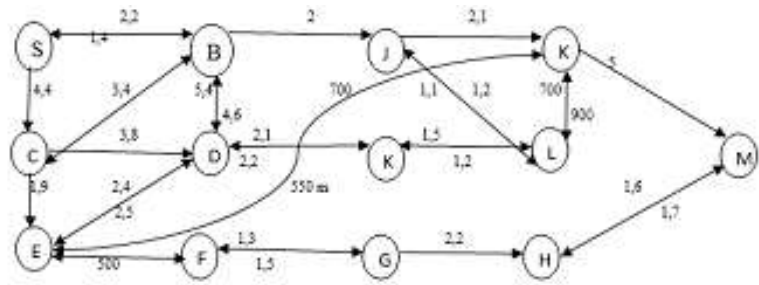

Gambar 1. Tahap pertama algoritma Bellman-Ford

Keterangan :

1. A - B : JNE $\leftrightarrow$ Juanda

2. $\mathrm{A}-\mathrm{C}: \mathrm{JNE} \rightarrow$ Mangonsidi

3. $\mathrm{B}-\mathrm{C}:$ Juanda $\leftrightarrow$ Mangonsidi

4. $\mathrm{C}-\mathrm{D}:$ Mangonsidi $\rightarrow$ Padang Bulan

5. B - D : Juanda $\leftrightarrow$ Padang Bulan

6. $\mathrm{C}-\mathrm{E}:$ Mangonsidi $\rightarrow$ Iskandar Muda

7. D - E : Padang Bulan $\leftrightarrow$ Iskandar Muda

8. E - F : Mangonsidi $\leftrightarrow$ Gajah Mada

9. $\mathrm{F}-\mathrm{G}:$ Gajah Mada $\leftrightarrow$ Darussalam

10. $\mathrm{G}-\mathrm{H}:$ Darussalam $\rightarrow$ Gatot Subroto

11. H - I : Gatot Subroto $\longrightarrow$ Helvetia

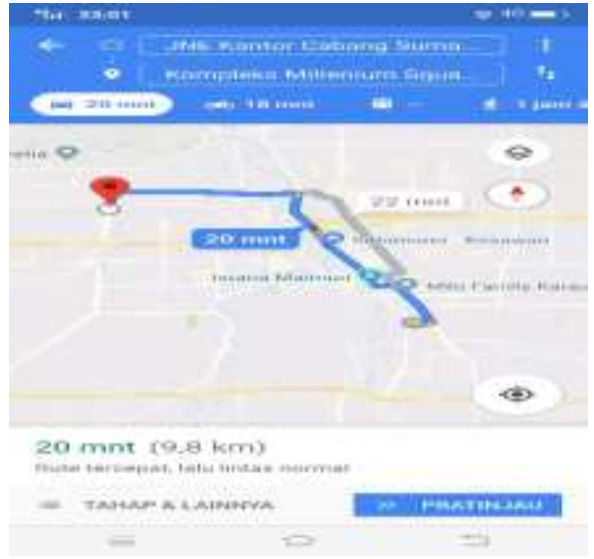

Gambar 2. Rute perjalanan dari PT. JNE Medan ke Helvetia

Pada gambar graf di atas terdapat 13 titik. Titik-titik tersebut merupakan batas-batas jalan, dimana titik A merupakan titik awal (JNE Bridgen Katamso). Berikut ini adalah jalur satu arah yang terdapat dari JNE Bridgen Katamso menuju Helvetia $\mathrm{A} \rightarrow \mathrm{C}$, titik $\mathrm{C} \rightarrow \mathrm{E}, \mathrm{C} \rightarrow \mathrm{D}, \mathrm{G} \rightarrow \mathrm{H}, \mathrm{B} \rightarrow \mathrm{I}, \mathrm{I} \rightarrow \mathrm{J}, \mathrm{J} \rightarrow \mathrm{M}$. Data jalan yang digunakan untuk mengetahui jalur terpendek dari JNE Bridgen Katamso ke semua titik (batas jalan). Satuan yang digunakan dalam jarak jalur ini adalah kilometer $(\mathrm{km})$.

Berikut penyelesaiannya secara manual 
1. Tahap pertama : Menentukan titik 1 sebagai titik awal dan mendaftar semua titik maupun sisi.

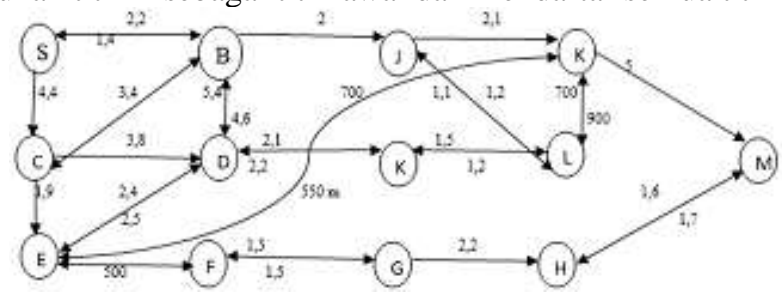

Gambar 3. Tahap pertama algoritma Bellman-Ford

2. Tahap kedua : memberi nilai untuk titik awal sama dengan nol dan yang lainnya tak terhingga

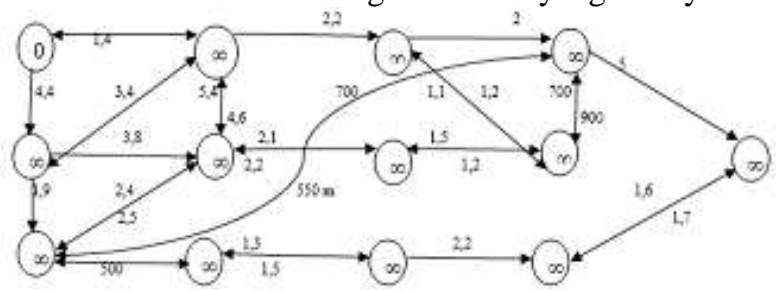

Gambar 4. Tahap kedua algoritma Bellman-Ford

2. Tahap ketiga : Iterasi pertama

$\mathrm{A} \rightarrow \mathrm{B}=0+2,2$

$$
=2,2
$$

3. Tahap ketiga : Iterasi kedua

$$
\begin{array}{rlrl}
\mathrm{B} \rightarrow \mathrm{C} & =2,2+3,4 & \mathrm{~B} \rightarrow \mathrm{I} & =2,2+2 \\
& =5,6 & =4,2 \\
\mathrm{~B} \rightarrow \mathrm{D} & =2,2+5,4 & \\
& =7,6 &
\end{array}
$$

4. Tahap ketiga : iterasi ketiga

$$
\begin{array}{rlrl}
\mathrm{C} \rightarrow \mathrm{B} & =5,6+2,2 & \mathrm{C} \rightarrow \mathrm{D}=5,6+3,8 \\
& =7,8 & =9,4 \\
\mathrm{C} \rightarrow \mathrm{E} & =5,6+1,9 & \\
& =7,5 &
\end{array}
$$

5. Tahap ketiga : iterasi keempat

$$
\begin{aligned}
\mathrm{D} \rightarrow \mathrm{B} & =9,4+4,6 \\
& =14 \\
\mathrm{D} \rightarrow \mathrm{E} & =9,4+2,4 \\
& =11,8
\end{aligned}
$$

$$
\begin{aligned}
\mathrm{D} \rightarrow \mathrm{K} & =9,4+2,1 \\
& =11,5
\end{aligned}
$$

6. Tahap ketiga : iterasi kelima

$$
\begin{array}{rlrl}
\mathrm{E} \rightarrow \mathrm{D} & =11,8+2,5 & \mathrm{E} \rightarrow \mathrm{J}=11,8+0,55 \\
& =14,3 & =12,35 \\
\mathrm{E} \rightarrow \mathrm{F} & =11,8+0,5 & \\
& =12,3 &
\end{array}
$$

7. Tahap ketiga : iterasi keenam

$$
\begin{array}{rlrl}
\mathrm{F} \rightarrow \mathrm{G} & =12,3+1,5 & \mathrm{G} \rightarrow \mathrm{H} & =13,8+2,2 \\
& =13,8 & & =16 \\
\mathrm{~B} \rightarrow \mathrm{I} & =2,2+2 & \mathrm{I} \rightarrow \mathrm{J} & =4,2+2,1 \\
& =4,2 & & =6,3 \\
\mathrm{~J} \rightarrow \mathrm{M}= & =6,3+5 & \mathrm{~J} \rightarrow \mathrm{L} & =6,8+0,9 \\
& =6,8 & & =7,7
\end{array}
$$

Berdasarkan hasil penelitian, terdapat 13 nama jalan yang diteliti dari PT. JNE Medan menuju Helvetia yang dituangkan dalam bentuk graf dimana terdapat 13 titik yang dicari rute terpendeknya. Dalam 13 titik tersebut merupakan batas-batas jalan. Gambar 4.1 sebagai rute PT. JNE Medan menuju Helvetia. Dari hasil penelitian di atas, untuk mencari rute terpendek melalui algoritma Bellman-Ford menggunakan dua cara yaitu menggunakan cara manual dan juga menggunakan bantuan Visual Basic. Penyelesaian pada kasus ini menggunakan algoritma Bellman-Ford menggunakan beberapa tahap. Namun sebelum menyelesaikan kasus ini terlebih dahulu perlu mencari jarak dari masing-masing titik. Pada penelitian ini menggunakan hasil pencarian dengan bantuan tool penunjuk arah pada google Maps.

Selanjutnya masuk kedalam algoritma pencarian jalur tependek dengan menggunakan Algoritma BellmanFord. Tahap ke-1 adalah menentukan titik 1 sebagai titik awal dengan memberi simbol S dan mendaftar semua 
titik maupun sisi sebagaimana terdapat pada Gambar 4.2. Setelah itu memberi nilai titik awal sama dengan nol (0) dan yang lainnya tak terhingga, terdapat pada Gambar 4.3.

Selanjutnya proses iterasi terhadap semua titik untuk menentukan jarak dari semua titik yang berhubungan dengan titik asal dengan cara:

Jika jarak V lebih besar dari jarak U+bobot UV maka jarak V diisi dengan jarak U+bobot UV. dimana U = titik asal, $\mathrm{V}=$ titik tujuan, $\mathrm{UV}=$ sisi yang menghubungkan $\mathrm{U}$ dan V. Langkah ini dilakukan sehingga semua titik terkunjungi. Berdasarkan hasil pencarian rute minimum dari titik awal ke semua titik dengan menggunakan algoritma Bellman-Ford terdapat enam proses iterasi.

Berikut rute minimum dari titik A ke semua titik yang peroleh dari proses iterasi tersebut sebagai berikut:

1. Iterasi pertama

Iterasi pertama terdapat pada gambar 4.5 dimulai dari titk yang berhubungan dengan titik awal, yaitu dari titik A ke titik B. Pada iterasi pertama jarak untuk titik B diisi dengan bobot titik A ditambah dengan jarak dari titik A ke titik B yaitu $0+2,2=2,2 \mathrm{~km}$

2. Iterasi kedua

Iterasi kedua pada gambar 4.6 yaitu iterasi dari titik B ke titik C, titik D dan titik I. Pada iterasi kedua titik C diisi dengan jarak dari titik $\mathrm{A}$ ke titik $\mathrm{C}$ yang diperoleh pada iterasi kedua ditambah dengan jarak minimum dari titik B ke titik C yaitu 2,2 +5,4 = 7,6 dan untuk titk B ke titik I yaitu 2,2 +2,0 = 4,2

3. Iterasi ketiga

Iterasi ketiga pada gambar 4.7 yaitu iterasi dari titik $\mathrm{C}$ ke titik B, D, dan E. Untuk titik D diisi dengan jarak dari titik $C$ ke titik D yang diperoleh pada iterasi ketiga yaitu $5,6+3,8=9,4$ kemudian untuk titik $C$ ke titik $E$ yaitu $5,6+1,9=7,5$ dan untuk titik $\mathrm{C}$ ke titik B yaitu $5,6+2,2=7,8$

4. Iterasi keempat

Iterasi keempat terdapat pada gambar 4.8 yaitu iterasi dari titik D ke titik E, titik K dan titik B. Untuk titik E diisi dengan jarak dari titik D ke titik E yaitu 9,4 +2,4 = 11,8 Untuk titik D ke titik B ditambah dengan jarak minimum yaitu $9,4+4,6=14$. Kemudian untuk titik K diisi dengan jarak dari titik D ke titik K yaitu 9,4 $+2,1$ $=11,5$

5. Iterasi kelima

Iterasi kelima pada gambar 4.9 yaitu iterasi dari titik E ke titik F, D, J. Untuk titik F diisi dengn jarak dari titik E ke titik F yaitu $11,8+2,5=12,3$ kemudian untuk titik $E$ ke titik $D$ yaitu $11,8+2,5=14,3$. Untuk jarak dari titik E ke titik $\mathrm{J}$ yaitu $11,8+0,55=12,35$

6. Iterasi keenam

Iterasi keenam pada gambar 4.10 yaitu iterasi dari titik $\mathrm{F}$ ke titik $\mathrm{G}$, iterasi dari titik $\mathrm{G}$ ke titik $\mathrm{H}$, iterasi dari titik B ke titik I, dari titik I ke titik J, dan dari titik J ke titik M dan titik L. Untik titik J diisi dengan jarak dari titik I ke titik J yaitu 4,2 $+2,1=6,3$

Berikut rute minimum dari titik A ke semua titik yang diperoleh dari proses iterasi

1. Rute dari titk A ke titik B

Dari titik A ke titik B hanya ada satu rute yang bisa dilewati sehingga dengan mudah diketahui rute minimumnya, namun berdasarkan algoritma Bellman-Ford dari titik A ke titik B diperoleh iterasi pertama yaitu dari titik $\mathrm{A} \rightarrow \mathrm{B}$ dengan jarak $2,2 \mathrm{~km}$.

2. Rute dari titk A ke titik $\mathrm{C}$

Sama halnya titik B, dari titik A ke titik C juga hanya terdapat 1 rute yang bisa dilewati yaitu titik $\mathrm{A} \rightarrow \mathrm{B} \rightarrow \mathrm{C}$ dengan jarak $5,6 \mathrm{~km}$. Sehingga rute tersebut merupakan rute minimum.

3. Rute dari titk A ke titik D

Rute dari titik A ke titik D ada beberapa jalur yang bisa dilewati dengan melewati titik $\mathrm{C}$, akan tetapi berdasarkan algoritma Bellman-Ford rute dari titik A ke titik D yaitu titik A $\rightarrow \mathrm{B} \rightarrow \mathrm{C} \rightarrow \mathrm{D}$ dengan jarak $9,4 \mathrm{~km}$.

4. Rute dari titk A ke titik E

Dari titk A ke titik E juga terdapat beberapa rute yang bisa dilewati, namun adapun beberapa rute minimum 4yang diperoleh titik $\mathrm{A} \rightarrow \mathrm{B} \rightarrow \mathrm{C} \rightarrow \mathrm{D} \rightarrow \mathrm{E}$ dengan jarak $11,8 \mathrm{~km}$.

5. Rute dari titik A ke titik $\mathrm{F}$

Sama halnya titik $\mathrm{C}$ dan $\mathrm{E}$, untuk sampai ke titik $\mathrm{F}$ juga ada beberapa rute yang paling minimum yaitu titik $\mathrm{A} \rightarrow \mathrm{B} \rightarrow \mathrm{C} \rightarrow \mathrm{D} \rightarrow \mathrm{E} \rightarrow \mathrm{F}$ dengan jarak $12,3 \mathrm{~km}$

6. Rute dari titik A ke titik $\mathrm{G}$

Adapun rute minimum dari titik A ke G yang diperoleh yaitu titik $\mathrm{A} \rightarrow \mathrm{B} \rightarrow \mathrm{C} \rightarrow \mathrm{D} \rightarrow \mathrm{E} \rightarrow \mathrm{F} \rightarrow \mathrm{G}$ dengan jarak 13,8 $\mathrm{km}$.

7. Rute dari titik A ke titik $\mathrm{H}$

Adapun rute minimum dari titik A ke $\mathrm{H}$ yang diperoleh yaitu titik $\mathrm{A} \rightarrow \mathrm{B} \rightarrow \mathrm{C} \rightarrow \mathrm{D} \rightarrow \mathrm{E} \rightarrow \mathrm{F} \rightarrow \mathrm{G} \rightarrow \mathrm{H}$ dengan jarak $16 \mathrm{~km}$.

8. Rute dari titik A ke titik I

Adapun rute minimum dari titik A ke I yang diperoleh yaitu titik $\mathrm{A} \rightarrow \mathrm{B} \rightarrow \mathrm{I} \quad$ dengan jarak 4,2 km.

9. Rute dari titik A ke titik J 
Rute minimum dari titik A ke titik J diperoleh iterasi keempat. Adapun rutenya yaitu $\mathrm{A} \rightarrow \mathrm{B} \rightarrow \mathrm{I} \rightarrow \mathrm{J}$ dengan jarak $6,3 \mathrm{~km}$

10. Rute dari titik A ke titik K

Rute minimum dari titik A ke titik J diperoleh iterasi keempat. Adapun rutenya yaitu $A \rightarrow B \rightarrow D$ dengan jarak $11,5 \mathrm{~km}$

11. Rute dari titik A ke titik $\mathrm{L}$

Rute minimum dari titik A ke titik J diperoleh iterasi keempat. Adapun rutenya yaitu $A \rightarrow B \rightarrow I \rightarrow J$ dengan jarak

$7,2 \mathrm{~km}$

12. Rute dari titik A ke titik $M$

Rute minimum dari titik A ke titik M yaitu $\mathrm{A} \rightarrow \mathrm{B} \rightarrow \mathrm{H} \longrightarrow \mathrm{M}$ dengan jarak $14,1 \mathrm{~km}$.

13. Rute dari titik B ke titik D

Rute minimum dari titik B ke titik D yaitu B $\rightarrow$ D dengan jarak 7,6 km.

\section{KESIMPULAN}

Berdasarkan hasil dan pembahasan dapat disimpulkan :

1. Penelitian ini terdapat 13 nama jalan yang diteliti yang akan dicari rute minimumnya, dimana 13 titik tersebut merupakan batas-batas jalan. Pada hasil penelitian untuk menghitung rute terpendek dengan menggunakan Algoritma Bellman-Ford dilakukan dengan dua cara yaitu dengan cara manual dan dengan menggunakan Visual Basic Net 2008.

2. Algoritma Bellman-Ford digunakan untuk mengetahui lintasan minimum yang akan ditempuh dalam pencarian rute terpendek sehingga mempermudah dalam pengantaran barang terhadap konsumen.

\section{REFERENCES}

[1] H. Sunandar, "STUDI TENTANG PENYELAMATAN TRAVELING SALESMAN DENGAN MENGGUNAKAN METODE REDUKSI PADA TEORI GRAF ( Studi Kasus : Perusahaan Kimia Farma ),” no. September, pp. 21-24, 2014.

[2] R. Munir, MATEMATIKA DISKRIT, Ketiga. 2010.

[3] R. Munir, MATEMATIKA DISKRIT, Kelima. BANDUNG, 2012.

[4] M. Santika, S. Hansun, and J. First, "Implementasi Algoritma Shortest Job First dan Round Robin pada Sistem Penjadwalan Pengiriman Barang,” vol. VI, no. 2, pp. 94-99, 2014.

[5] T. Dengan, A. Semut, and D. A. N. Algoritma, "Pemanfaatan Metode Heuristik dalam Pencarian Jalur Terpendek dengan Algoritma Semut dan Algoritma Genetika," no. January 2017, 2007.

[6] Jogiyanto, Analisis \& Desain Sistem Informasi. Yogyakarta: ANDI, 2005.

[7] R. H. S., Visual Basic 2008 for Pemula Banget. Jakarta: PT.Elex Media Komputindo, 2009. 